\title{
BIOMONITORING OF A POPULATION RESIDING NEAR TO MINE TAILINGS IN GUANAJUATO, MEXICO
}

\author{
Biomonitoreo de una población que reside cerca de jales mineros en Guanajuato, México
}

\author{
Rogelio COSTILLA SALAZAR ${ }^{1 *}$, Diana ROCHA AMADOR ${ }^{2}$, Tania RUIZ VERA ${ }^{3}$, \\ Gustavo CRUZ JIMÉNEZ2, Guillermo ESPINOSA REYES ${ }^{3}$, Gladys MORALES LÓPEZ², \\ Edelmira GARCÍA NIETO ${ }^{4}$ and Juan Ángel MEJÍA GÓMEZ ${ }^{1}$
}

\footnotetext{
${ }^{1}$ Universidad de Guanajuato, División de Ciencias de la Vida, Carretera Irapuato-Silao Km 9, Ex Hacienda El Copal, 36500, Irapuato, Guanajuato, México

${ }^{2}$ Universidad de Guanajuato, División de Ciencias Naturales y Exactas, Noria Alta s/n, 36050, Guanajuato, México

${ }^{3}$ Universidad Autónoma de San Luis Potosí, Sierra Leona 550, Lomas 2da Sección, 78210, San Luis Potosí, México

${ }^{4}$ Universidad Autónoma de Tlaxcala, Autopista San Martín-Tlaxcala Km 10.5, 90120, Ixtacuixtla, Tlaxcala, México

*Corresponding author: roy1379@hotmail.com
}

(Received: November 2017; accepted: January 2020)

Key words: lead, arsenic, genotoxicity, mine tailings

\begin{abstract}
Some metals present in residues coming from mining activities can damage DNA. A preliminary evaluation was carried out to determine the genotoxic effects on a resident population from a mining area in Xichú, Guanajuato, Mexico. Blood lead levels (BLL), and arsenic levels in urine (AsU), were measured as biomarkers of exposure. Hematological damage was evaluated trough hematocrit, hemoglobin and activity of enzyme delta-aminolevulinic dehydratase ( $\delta$-ALAD). DNA damage in blood cells was evaluated by comet assay. BLL $(7.5 \pm 1.2$ and $7.9 \pm 3.3 \mu \mathrm{g} / \mathrm{dL})$ and $\mathrm{AsU}(25.2 \pm 15.8$ and $18.3 \pm 18.4 \mu \mathrm{g} / \mathrm{g}$ creatinine) were found in children and adults, respectively. Of the children and adults, 100 and $91.7 \%$, respectively had levels of enzyme activity below $20 \mathrm{U} / \mathrm{L}$ erythrocytes. Regarding DNA damage, the children showed an Olive tail moment of $5.0 \pm 1.6$ and a tail length of $40.9 \pm 4.9 \mu \mathrm{m}$, of similar magnitude than adults ( $4.6 \pm 1.0$ and $41.8 \pm 5.9 \mu \mathrm{m}$, respectively). In conclusion, this preliminary study describes the health risk scenario of population near the mine, nevertheless, more studies are needed in the area.
\end{abstract}

Palabras clave: plomo, arsénico, genotoxicidad, jales mineros

\section{RESUMEN}

Algunos metales presentes en residuos provenientes de actividades mineras pueden dañar al ADN. Se llevó a cabo una evaluación preliminar para determinar efectos genotóxicos en población residente de un área minera en Xichú, Guanajuato, México. Los niveles de plomo en sangre ( $\mathrm{PbS}$ ) y los niveles de Arsénico en orina (AsO) fueron 
medidos como biomarcadores de exposición. El daño hematológico se evaluó por medio del hematocrito, la hemoglobina y la actividad de la enzima acido delta-aminolevulínico dehidrasa $(\delta$-ALAD). El daño al ADN fue evaluado a través del ensayo cometa. Niveles de $\mathrm{PbS}(7.5 \pm 1.2$ y $7.9 \pm 3.3 \mu \mathrm{g} / \mathrm{dL})$ y $\mathrm{AsO}(25.2 \pm 15.8$ y $18.3 \pm 18.4 \mu \mathrm{g} / \mathrm{g}$ creatinina $)$ fueron encontrados en niños y adultos, respectivamente. De éstos, el $100 \%$ de los niños y el $91.7 \%$ de los adultos tuvieron niveles de actividad de la enzima menor que 20 U/L eritrocitos. Respecto al daño en el ADN, los niños mostraron un momento de cola $(5.0 \pm 1.6)$ y una longitud de cola $(40.9 \pm 4.9 \mu \mathrm{m})$ de similar magnitud que los adultos $(4.6 \pm 1.0$ y $41.8 \pm 5.9 \mu \mathrm{m})$. En conclusión, este estudio preliminar describe el escenario de riesgo en salud de la población cercana a la mina; sin embargo, se necesitan más estudios en el área.

\section{INTRODUCTION}

The Xichú mining district is in the northeast of the state of Guanajuato, Mexico. Mining activity began in the colonial era and ended in the mid-twentieth century. The most important mine in this district is La Aurora, which profited from metals such as silver (Ag) and gold (Au) (Miranda-Gasca 1978). Due to mining activity in the area, four tailings were disposed in the surroundings.

One of the main problems arising from the improper disposal of mine tailings is the introduction of potentially toxic elements into the environment (Ramos-Arroyo et al. 2004, Ramos-Arroyo and Siebe-Grabach 2006). Previous geochemical studies in the zone indicated the presence of copper $(\mathrm{Cu})$, zinc $(\mathrm{Zn})$, silver $(\mathrm{Ag})$, lead $(\mathrm{Pb})$ and arsenic $(\mathrm{As})$ in different environmental matrices (Salas-Megchún 2014, Loredo-Portales et al. 2015, 2017).

The highest levels of $\mathrm{Pb}$ and $\mathrm{As}$ found in tailings and soils from the zone of La Aurora, could represent a risk for the surrounding populations.

There have been numerous studies regarding exposure to metals in human population from mining zones (García-Vargas et al. 2001, Moreno et al. 2010). An effect reported in populations living in this risk scenery is DNA damage (Yáñez et al. 2003, JassoPineda et al. 2012). The genotoxicity of $\mathrm{As}$ and $\mathrm{Pb}$ is well demonstrated both in animals (Saleha-Banu et al. 2001, Martínez-Alfaro et al. 2012) and in humans (Méndez-Gómez et al. 2008).

A helpful tool used in the assessment of early biological effects like DNA damage in populations exposed to environmental pollution is the comet assay (Jasso-Pineda et al. 2015). Therefore, the aim of this work was to conduct biomonitoring of As and $\mathrm{Pb}$, as well as to identify the potential genotoxic effects of these elements in a population of children and adults exposed to mine tailings in the vicinity of the Aurora mine in the mining district of Xichú, Mexico.

\section{MATERIALS AND METHODS}

The Aurora mine is located $6 \mathrm{~km}$ from the town of Xichú, Guanjuato, México. It is an abandoned mine site that has four tailing deposits exposed to the environment, so they are prone to incidents of leaching and suspension by wind and water. The waste was generated when there was no environmental regulation and may be considered as an environmental liability; it does not meet the requirements of the Mexican Official Standard NOM-141-SEMARNAT-2003 (SEMARNAT 2005), which establishes the criteria for the construction, operation and post-operation of tailing dams.

To confirm the presence of potentially toxic elements at the site such as $\mathrm{Pb}$ and $\mathrm{As}$, a targeted soil sampling was performed (at a depth of $0-5 \mathrm{~cm}$ ) in the tailing located between the communities Adjuntas and La Fundición (900 and $600 \mathrm{~m}$ away from the tailing, respectively).

A total of five samples were selected, one directly in the tailing, one near the tailing and three around the tailing. Samples around the tailing (less than 20 $\mathrm{m}$ away from the tailing) were selected in areas able to be in direct contact with the people from surrounding communities.

Figure 1 shows the area of the mining district (UTM $393231 \mathrm{~N}, 2359598 \mathrm{~W}$ ), location of the tailings, localities, and sampled soil points.

Samples of tailing and soils were sieved in particles smaller than $0.85 \mathrm{~mm}$ and digested according to the Environmental Protection Agency (EPA) method 3050B.

The $\mathrm{Pb}$ analysis in the environmental samples was performed by an atomic absorption spectrophotometer (AAS) (Perkin-Elmer model AAnalyst 400) using the flame technique.

For the analysis of As, special treatment was given to the digested samples, adding potassium iodide (KI) at $2 \%$ for $30 \mathrm{~min}$ in the dark. Determination of As 


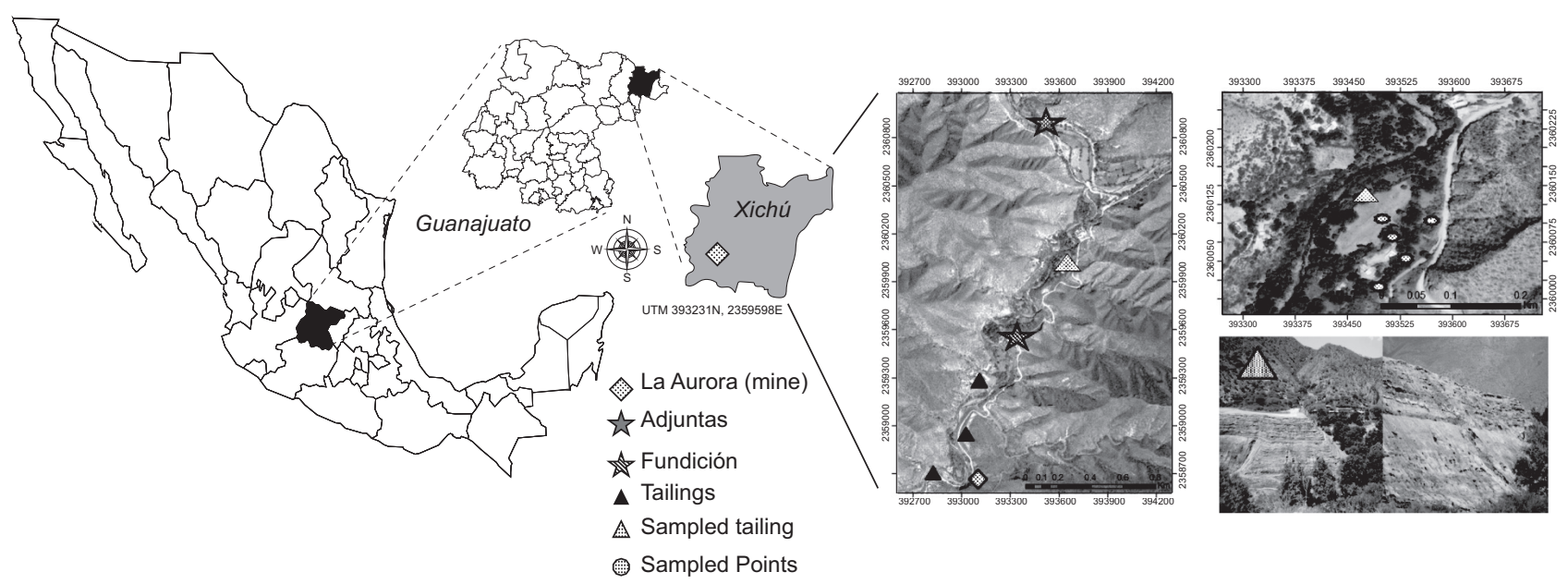

Fig. 1. Location of the study site (UTM 393231 N, 2359598 W), tailings and sampled points

was performed by an AAS coupled to a continuous flow injection in a reaction with a $3 \% \mathrm{NaBH}_{4}$ and $1 \% \mathrm{NaOH}$ solution, using $\mathrm{HCl}$ at $1.5 \%$ as a reaction medium.

The detection limit (DL) was $0.15 \mathrm{mg} / \mathrm{kg}$ for $\mathrm{Pb}$ and $0.35 \mathrm{mg} / \mathrm{kg}$ for As. For quality control, we used the standard reference of the National Institute of Standards and Technology (NIST) using the Montana 2711a soil and the Montana Soil II, getting an accuracy of $91.7 \%$ for $\mathrm{Pb}$ and $85 \%$ for As.

For biological monitoring, residents from Adjuntas and La Fundición were invited to participate in the study.

The inclusion criteria for children were age between 6 to 12 years, having lived in the community since birth and the consent of the parent or guardian. For adults, the inclusion criteria were legal age, having lived in the community at least for 5 years and a letter of consent signed by the participant.

The research was approved by an ethical committee. The total population of both communities is 182 inhabitants. Fifty-two were children (younger than 12 years of age) and 96 adults (INEGI 2010).

Only 20 children and 20 adults participated in the study, representing the 38 and $20 \%$, respectively of the total population.

Malnutrition was evaluated by anthropometric indices. Weight and height for age were used like indicators of acute and chronic malnutrition in children, respectively, and the Body Mass Index (BMI) was used like indicator of malnutrition in adults. All participants were weighed and measured with a scale and stadiometer (Seca).

Hematocrit $(\mathrm{Ht})$ was determined by centrifuging blood in heparinized capillary tubes $(50 \mu \mathrm{L})$ at
$7000 \mathrm{rpm}$ for $10 \mathrm{~min}$ in a $\mathrm{Ht}$ centrifuge (Sol Bat $\mathrm{M}-08$ ). Measurement was done with a Ht standard chart (Critops tube reader). The hemoglobin content $\mathrm{(Hb})$ was measured using a diagnostic kit (HemoCueHb 201 Microcuvettes and $\mathrm{HemoCueHb} 201$ Analyzer). The test was performed according to the protocol of the instrument operation manual.

The activity of enzyme delta-aminolevulinic dehydratase ( $\delta$-ALAD) was determined according to the standardized European method (Berlin and Schaller 1974). The enzyme activity was expressed as $\mu \mathrm{mol} /$ min per liter erythrocytes.

The blood $\mathrm{Pb}$ samples were analyzed with an inductively coupled plasma mass spectrometry (ICP-MS) at the Centro de Innovación Aplicada en Tecnologías Competitivas (Center for Applied Innovation in Competitive Technologies, CIATEC), Mexico, while for the analysis of As, $5 \mathrm{~mL}$ of urine acid digestion were used following the Cox method (Cox 1980). The As analysis was carried out with the AAS in the same manner as the soil samples. For quality control, the standard ClinChek Urine Control lyophilized for trace elements from IRIS Technologies was used obtaining an accuracy of $87 \%$ for As. The As concentration in urine was corrected by the urine creatinine value, which was determined by the Jaffe colorimetric method (Singh et al. 1988), using a Randox kit for creatinine.

Assessment of genotoxic damage was carried out in the study population following the comet assay protocol described by Singh et al. (1988). One hundred cells were counted per sample in a Nikon Eclipse E400 epifluorescence microscope using the Komet 4.0 image analysis software (Kinetic Imaging, Liverpool, UK). Measurements of DNA damage were 
obtained with the Olive Tail Moment (OTM) and the Tail Length (TL).

Descriptive and exploratory data analysis for continuous variables $(\mathrm{Pb}$ in soil, $\mathrm{As}$ in soil, age, $\mathrm{z}$ height by age, $\mathrm{z}$ weight by age, $\mathrm{BMI}, \mathrm{Pb}$ in blood, As in urine, OTM, TL, Ht, $\mathrm{Hb}$ and $\delta$-ALAD) and a descriptive analysis with respect to categorical variables (gender) were done. The results were presented for children and adults. OTM did not assume a normal distribution. The variable was log-transformed and reported as geometric mean and standard deviation. Bivariate analysis was made through the Pearson correlation. Correlations were worked in an independent way for children and adults. The statistical analyses were carried out using SPSS statistical software package v. 19.0.

\section{RESULTS AND DISCUSSION}

$\mathrm{Pb}$ levels in the tailing sample exceeded 9.2 times the reference concentration of $400 \mathrm{mg} / \mathrm{kg}$ for residential/agricultural land (NOM-147-SEMARNAT/ SSA1-2004) (SEMARNAT 2007), while in the soil samples taken from the surroundings of the mine tailing $(1104 \mathrm{mg} / \mathrm{kg})$ and from a nearby river $(535$ $\mathrm{mg} / \mathrm{kg}$ ), the levels exceeded 2.8 and 1.3 times the reference value, respectively (Table I).

Regarding As, the mine tailing sample highly exceeded the limits set by Mexican regulations. Soil samples exceeded from 2.4 to 66.9 times the reference value of $22 \mathrm{mg} / \mathrm{kg}$, being the soil near the mine tailing (Table I) the one with the highest level.

Salas-Megchún (2014) made a geochemical characterization of the tailings from La Aurora. The levels of $\mathrm{Pb}$ and $\mathrm{As}$ in tailing 3 (the same one sampled in

TABLE I. CONCENTRATIONS OF LEAD (mg/kg) AND ARSENIC $(\mathrm{mg} / \mathrm{kg})$ IN THE TAILINGS AND SOILS FROM THE AURORA MINE IN XICHÚ, GUANAJUATO*

\begin{tabular}{lcc}
\hline Zone & $\mathrm{Pb}(\mathrm{mg} / \mathrm{kg})$ & As $(\mathrm{mg} / \mathrm{kg})$ \\
\hline Tailing & 3699.1 & 307338.4 \\
Soil near tailing & 1104.0 & 1473.0 \\
Soil 1 & 262.0 & 323.0 \\
Soil 2 & 535.0 & 204.0 \\
Soil 3 & 258.0 & 52.0 \\
\hline
\end{tabular}

*The Official Mexican Standard NOM-147-SEMARNAT/ SSA1-2004 (SEMARNAT 2007) establishes limits of $800 \mathrm{mg} / \mathrm{kg}$ for $\mathrm{Pb}$ and $260 \mathrm{mg} / \mathrm{kg}$ for As in industrial lands, and $400 \mathrm{mg} / \mathrm{kg}$ for $\mathrm{Pb}$ and $22 \mathrm{mg} / \mathrm{kg}$ for $\mathrm{As}$ in residential/agricultural lands our study) were between 699-14945 and 2329-38631 $\mathrm{mg} / \mathrm{kg}$ for $\mathrm{Pb}$ and $\mathrm{As}$, respectively. Regarding the soil samples, levels were less than the DL for $\mathrm{Pb}$ and $\mathrm{As}$ (3379 and $4708 \mathrm{mg} / \mathrm{kg}$, respectively).

Similarly, in an earlier study, Loredo-Portales et al. (2017) evaluated the same tailing sampled in our study and reported As levels between 3290-12469 and $181-719 \mathrm{mg} / \mathrm{kg}$ in the mine tailing and nearby soils, respectively.Our results were similar to these reports. Loredo-Portales (2017) also reported the levels of bio-accessible As (As available to enter the human body). The percentage of bio-accessibility was less than $10 \%$ for mine tailing samples, whereas for soil it was near to $20 \%$. Although the percentage of bio-accessibility is low, it represents a risk due to the high concentration of As in the sample. These data show the magnitude of contamination in this site.

The possible routes of exposure to these metals in the impacted zone are the suspension of mine tailings by the wind and the resuspension of soil particles generated by activities on roads. The predominant winds in the region are trade winds from the northwest, supporting this exposure route (Martínez-Arredondo et al. 2013). The residents of Adjuntas and La Fundición travel on the main road (which is less than $20 \mathrm{~m}$ away from the tailings) for their everyday activities. It is important to mention that there are houses settled over the tailings.

In Mexico, the recommended $\mathrm{Pb}$ values in blood for a non-occupational population were $10 \mu \mathrm{g} / \mathrm{dL}$ in children and $25 \mu \mathrm{g} / \mathrm{dL}$ in adults (NOM-199-SSA1-2000) (SSA 2002). However, based on neurotoxicity studies in children (Canfield et al. 2003), the recommended value for children was reduced to $5 \mu \mathrm{g} / \mathrm{dL}$ (SSA2017).

In the present study, $100 \%$ of the children presented values over $5 \mu \mathrm{g} / \mathrm{dL}$ (Table II). Regarding As in urine, a small percentage of children $(12.5 \%)$ and adults $(12.5 \%)$ exceeded the limits set by the CDC of $50 \mu \mathrm{g} / \mathrm{g}$ creatinine (Table II).

Trejo-Acevedo et al. (2009) conducted a study in several polluted areas of Mexico. Children from two mining sites were monitored (Comarca Lagunera, Durango, and Zacatecana, Zacatecas), finding $\mathrm{Pb}$ blood levels of $3.7 \pm 1.49$ and $6.0 \pm 1.8 \mu \mathrm{g} / \mathrm{dL}$, respectively, while the levels of As in urine were 33.8 \pm 13.7 and $26 \pm 9.8 \mu \mathrm{g} / \mathrm{g}$ for creatinine.

Our results were higher in terms of $\mathrm{Pb}$ in blood (children, $7.5 \mu \mathrm{g} / \mathrm{dL}$; adults, $7.9 \mu \mathrm{g} / \mathrm{dL}$ ), but similar with respect to As in urine $(25.2$ and $18.3 \mu \mathrm{g} / \mathrm{g}$ creatinine in children and adults, respectively). Yáñez et al. (2003) evaluated children living in Villa de la Paz, San Luis Potosí, Mexico $(\mathrm{n}=20)$, a mine site contaminated with $\mathrm{Pb}$ and $\mathrm{As}$ (with marginalization 
TABLE II. GENERAL CHARACTERISTICS, AND NUTRITIONAL, HEMATOLOGICAL AND CONTAMINANT LEVELS IN THE STUDY POPULATION

\begin{tabular}{|c|c|c|c|}
\hline & & $\begin{array}{l}\text { Children } \\
(\text { min-max })^{\mathrm{a}}\end{array}$ & $\begin{array}{c}\text { Adults } \\
(\text { min-max })^{\mathrm{a}}\end{array}$ \\
\hline Age (years) & & $10.8 \pm 2.2(6-12)$ & $42.4 \pm 17.9(18-49)$ \\
\hline Gender & $\begin{array}{l}\text { male } \\
\text { female }\end{array}$ & $\begin{array}{l}58.8 \% \\
41.2 \%\end{array}$ & $\begin{array}{l}56.3 \% \\
43.8 \%\end{array}$ \\
\hline$z$ height by age & $>-2 \mathrm{SD}^{\mathrm{b}}$ & $0 \%$ & NA \\
\hline z weight by age & $>-2 \mathrm{SD}^{\mathrm{b}}$ & $6.3 \%$ & NA \\
\hline Body Mass Index & $>25 \mathrm{~kg} / \mathrm{cm}^{2}$ & NA & $90 \%$ \\
\hline Haemoglobin $(\mathrm{g} / \mathrm{dL})$ & $\begin{array}{c}<11.2^{\mathrm{c}} \\
<13.5 \mathrm{M},<12.5 \mathrm{~F}^{\mathrm{c}}\end{array}$ & $\begin{array}{c}14.3 \pm 0.8(13.2-15.9) \\
0 \% \\
\text { NA }\end{array}$ & $\begin{array}{c}14.7 \pm 1.4(11.7-16.6) \\
\text { NA } \\
0 \%\end{array}$ \\
\hline $\begin{array}{l}\text { Hematocrit } \\
\text { (\% erythrocytes) }\end{array}$ & $\begin{array}{c}<35^{\mathrm{c}} \\
<40 \mathrm{M},<37 \mathrm{~F}^{\mathrm{c}}\end{array}$ & $\begin{array}{c}57.3 \pm 3.9(53-65) \\
0 \% \\
\text { NA }\end{array}$ & $\begin{array}{c}58.6 \pm 5.5(50-69) \\
\text { NA } \\
12.5 \%\end{array}$ \\
\hline $\begin{array}{l}\text { Delta-aminolevulinic acid dehydratase } \\
\text { activity ( } \mu \mathrm{mol} / \mathrm{min} \text { per liter erythrocytes) }\end{array}$ & $<20^{\mathrm{d}}$ & $\begin{array}{c}14.1 \pm 3.1(7.2-19.5) \\
100 \%\end{array}$ & $\begin{array}{c}13.2 \pm 4.2(6.4-21.5) \\
93.8 \%\end{array}$ \\
\hline Lead in blood $(\mu \mathrm{g} / \mathrm{dL})$ & $\begin{array}{l}>5^{\mathrm{e}} \\
>10^{\mathrm{e}}\end{array}$ & $\begin{array}{c}7.5 \pm 1.2(5.1-9.3) \\
100 \% \\
0 \%\end{array}$ & $\begin{array}{c}7.9 \pm 3.3(4.8-17.8) \\
91.7 \% \\
8.3 \%\end{array}$ \\
\hline Arsenic in urine ( $\mu \mathrm{g} / \mathrm{g}$ creatinine) & $>50^{\mathrm{f}}$ & $\begin{array}{c}25.2 \pm 15.8(7.5-65.2) \\
12.5 \%\end{array}$ & $\begin{array}{c}18.3 \pm 18.4(0.8-65.1) \\
12.5 \%\end{array}$ \\
\hline
\end{tabular}

NA: does not apply, arithmetic mean \pm standard deviation (SD) (minimum and maximum), benchmark by WHO, ${ }^{c}$ minimum reference values (M: male, F: female), ${ }^{d}$ reference value to healthy people not exposed to $\mathrm{Pb}$, ${ }^{\mathrm{e}} \mathrm{NOM}-199-$ SSA1-2000, ${ }^{\mathrm{f}} \mathrm{CDC}$ reference values

status similar to La Aurora), and compared them with a population of lower exposure (Matehuala, San Luis Potosí, Mexico; $\mathrm{n}=35)$. At the exposed site, blood $\mathrm{Pb}$ levels $(11.6 \mu \mathrm{g} / \mathrm{dL})$ and As in urine $(136 \mu \mathrm{g} / \mathrm{g}$ creatinine) were higher than those found in Matehuala $(\mathrm{Pb}, 8.3 \mu \mathrm{g} / \mathrm{dL}$; As, $34 \mu \mathrm{g} / \mathrm{g}$ creatinine $)$.

Four years later, Jasso-Pineda et al. (2007) conducted a risk assessment in the same site. They found a slight reduction in urinary As in children of Villa de la Paz (Pb, $13.8 \pm 1.0 \mu \mathrm{g} / \mathrm{dL}$; As, $52.1 \pm 7.5 \mu \mathrm{g} / \mathrm{g}$ creatinine) and Matehuala $(\mathrm{Pb}, 7.3 \pm 1.5 \mu \mathrm{g} / \mathrm{dL} ; \mathrm{As}$, $16.8 \pm 1.6 \mu \mathrm{g} / \mathrm{g}$ creatinine).

In the present study, the blood $\mathrm{Pb}$ levels and $\mathrm{As}$ in urine are similar to those found in the population of lower exposure (Matehuala). In all the places studied, including the control site of Matehuala, $\mathrm{Pb}$ levels found are inconveniently high for children health and development.

With respect to hematological parameters, $\mathrm{Hb}$ levels were found to be within ethe stablished clinical parameters for children $(14.3 \pm 0.8 \mathrm{~g} / \mathrm{dL})$ and adults
$(14.7 \pm 1.4 \mathrm{~g} / \mathrm{dL})$. The studied population had very high Ht values (children, $57.3 \pm 3.9 \%$ erythrocytes; adults, $58.6 \pm 5.5 \%$ erythrocytes $)$, a disorder known as polycythemia (Table II).

This parameter varies significantly in different populations according to several factors, one of them being altitude. Nevertheless, it has also been observed in animals as a response mechanism for secondary anemia caused by $\mathrm{Pb}$. Concerning the activity of the $\delta$-ALAD enzyme, several studies mention that $\mathrm{Pb}$ inhibits the activity of $\delta$-ALAD at concentrations between 5 to $50 \mathrm{mg} / \mathrm{dL}$. In the present study, 100 and $91.7 \%$ of the children and adults, respectively, had enzyme activity levels lower than $20 \mu \mathrm{mol} / \mathrm{min}$ per liter of erythrocytes (Table II).

We did not find a relationship between $\mathrm{Pb}$ and $\delta$-ALAD. This may be due to the fact that most children and adults presented elevated levels of $\mathrm{Pb}$, more than $5 \mathrm{mg} / \mathrm{dL}$ (100\% and $93.8 \%$ respectively). It is necessary to increase the sample size to record different exposure levels. 
The nutritional status is also a factor that can influence the biomarkers of exposure level and DNA damage (Peraza et al. 1998). The selected communities had a high degree of marginalization; however, both children and adults did not show malnutrition. Only $6.3 \%$ of the children presented more than two standard deviations (SD) in the $\mathrm{z}$ score of weight by age, the benchmark for acute malnutrition marked by WHO (2017). It is worth noting that most adults (90\%) had overweight or were obese (Table II).

Regarding DNA damage (Fig. 2), the average OTM was $5.0 \pm 1.6$ for children and $4.6 \pm 1.0$ for adults (Fig. 2a), while the average TL was $40.9 \pm$ 4.9 and $41.8 \pm 5.9 \mu \mathrm{m}$ for children and adults, respectively (Fig. 2b).

Bajpayee et al. (2002) reported a reference value of 4 for OTM in adults, similar to the OTM of 3.2 and 3.9 observed by Yáñez et al. (2003) and JassoPineda et al. (2007), respectively, in children residing in Matehuala (control group).

In our study, more than half of the population had OTM values greater than 4 (children, $64.3 \%$; adults,



b

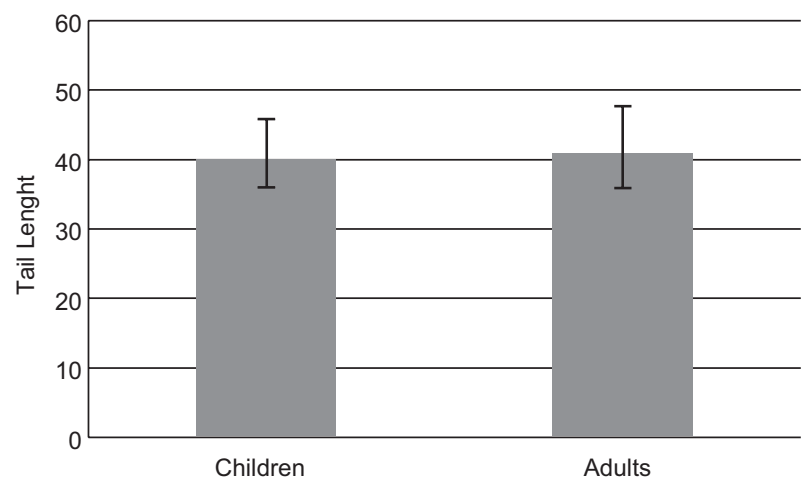

Fig. 2. DNA damage assessed by the comet assay in children and adults residing near the Aurora Mine in Xichú, Guanajuato. Values are geometric mean \pm standard deviation. (a) Olive tail moment, (b) tail length.
$69.2 \%$ ). In the same control group from Matehuala, the average TL was 41.7 , while the children and adults from the mine zone of La Aurora showed 40.9 and $41.8 \mu \mathrm{m}$, respectively. In the exposed group of Villa de la Paz, studied by Yáñez et al. (2003) and Jasso-Pineda et al. (2007), OTM and TL values were 6.8 and $67.6 \mu \mathrm{m}$, respectively. In our population, only one child had a similar OTM value (7.1).

Jasso-Pineda et al. (2015) used OTM as a biomarker for biological effects in child populations living in contaminated areas. Also, they observed that the highest OTM values in children living in those sites were found in subjects with As in urine levels higher than $50 \mu \mathrm{g} / \mathrm{g}$ creatinine, a result that is not observed in children with blood $\mathrm{Pb}$ levels higher than $5 \mu \mathrm{g} / \mathrm{dL}$.

In our study, only $12.5 \%$ of the children and adults presents levels above $50 \mu \mathrm{g} / \mathrm{g}$ creatinine, which could be the reason that OTM values were lower in our population. We did not find a correlation between $\mathrm{Pb}$ in blood or As in urine with DNA damage variables. We only observed the tendency, but it was not significative, probably due to our small sample size or the low levels of As.

A major limitation of our study was that we did not evaluate a reference population, since a risk assessment is usually carried out simultaneously in exposed and non-exposed populations under the same nutritional and socioeconomic conditions, in order to correlate the biological effects.

The sample size was very small due to the fact that the population is small and the sampling was voluntary. The main reasons for refusing to participate in the study were the pain produced by the needle during the blood sampling, and the impossibility to participate in the study due to working reasons. In future studies it would be important to increase the sample size, a strategy could be to get involve more people from the region to give more confidence to the participant.

\section{CONCLUSION}

This is the first study to describe the health risk scenario for the population of the mining town La Aurora. The results showed detectable levels of $\mathrm{Pb}$ and $\mathrm{As}$ in biological matrices from children and adults, indicating an environmental exposure to these elements due to the mine tailing deposits present in the area.

The inactivation of $\delta$-ALAD levels was supported by to $\mathrm{Pb}$ levels in blood. $\mathrm{Pb}$ exposure was higher than $5 \mu \mathrm{g} / \mathrm{dL}$ where previous studies report biological effects, affecting mainly child population. 
In the case of As, a small percentage of the study population presented levels higher than the reference values, probably because this element was determined in urine, which is not the better biomarker for the principal exposure route to As in the site (mine tailing and soil particles). Nevertheless, we found detectable levels indicating As exposure. In this case, other matrices to determine As exposure could be nails or hair, and they should be used in upcoming studies.

The results obtained show the need to continue studying the area and creating risk communication programs in the site, in order to prevent contact with the tailing deposits and diminish the associated exposure.

\section{REFERENCES}

Bajpayee M., Dhawan A., Parmar D., Pandey A.K., Mathur N. and Seth P.K. (2002). Gender-related differences in basal DNA damage in lymphocytes of a healthy Indian population using the alkaline Comet assay. Mutat. Res. $520(1-2), 83-91$.

DOI: $10.1016 / \mathrm{S} 1383-5718(02) 00175-4$

Berlin A. and Schaller K.H. (1974). European standardized method for the determination of delta-aminolevulinic acid dehydratase activity in blood. Z. Klin. Chem. Klin. Biochem. 12 (8), 389-90.

DOI: $10.1007 / \mathrm{BF} 00378728$

Canfield R.L., Henderson C.R., Cory-Slechta D.A., Cox C., Jusko T.A. and Lanphear B.P. (2003). Intellectual impairment in children with blood lead concentrations below 10 micrograms per deciliter. N. Engl. J. Med. 348, 1517-1526. DOI: 10.1056/NEJMoa022848

Cox D.H. (1980). Arsine evolution-electrothermal atomic absorption method for the determination of nanogram levels of total arsenic in urine and water. J. Anal. Toxicol. 4 (4), 207-211. DOI: 10.1093/jat/4.4.207

García-Vargas G.G., Rubio-Andrade M., del Razo L.M., Borja-Aburto V., Vera-Aguilar E. and Cebrián M.E. (2001). Lead exposure in children living in a smelter community in Región Lagunera, Mexico. J. Toxicol. Environ. Health 62 (6), 417-429.

DOI: $10.1080 / 00984100150501150$

INEGI (2010). Censo de población y vivienda 2010. Instituto Nacional de Estadística y Geografía. [online]. https://www.inegi.org.mx/programas/ccpv/2010/default.html?init=2\#Datos_abiertos 12/11/2018

Jasso-Pineda Y., Espinosa-Reyes G., González-Mille D., Razo-Soto I., Carrizales L., Torres-Dosal A., MejíaSaavedra J., Monroy M., Ize A.I., Yarto M. and DíazBarriga F. (2007). An integrated health risk assessment approach to the study of mining sites contaminated with arsenic and lead. Integr. Environ. Assess. Manag. 3 (3), 344-350. DOI: 10.1007/s12011-011-9237-0

Jasso-Pineda Y., Díaz-Barriga F., Calderón J., Yáñez L., Carrizales L. and Pérez-Maldonado I.N. (2012). DNA damage and decreased DNA repair in peripheral blood mononuclear cells in individuals exposed to arsenic and lead in a mining site. Biol. Trace Elem. Res. 146 (2), 141-149.

DOI: $10.1007 / \mathrm{s} 12011-011-9237-0$

Jasso-Pineda Y., Díaz-Barriga F., Yáñez-Estrada L., PérezVázquez F.J. and Pérez-Maldonado I.N. (2015). DNA damage in Mexican children living in high-risk contaminated scenarios. Sci. Total Environ. 15 (518-519), 38-48. DOI: 10.1016/j.scitotenv.2015.02.073

Loredo-Portales R., Cruz Jiménez G., Castillo Michel H., Rocha Amador D.O., Vogel Mikus K., Kump P. and de la Rosa G. (2015). Understanding copper speciation and mobilization in soils and mine tailings from "Mineral La Aurora" in central Mexico: Contributions from synchrotron techniques. Bol. Soc. Geol. Mex. 67 (3), 447-456.

Loredo-Portales R., Castillo-Michel H., Aquilantic G., de La Rosa-Álvarez M.G., Rocha-Amador D.O., VogelMikusef K., Kumpf P. and Cruz-Jiménez G. (2017). Synchrotron based study of As mobility and speciation in tailings from a mining site in Mexico. Journal of Environmental Chemical Engineering 5 (1), 1140-1149. DOI: 0.1016/j.jece.2017.01.019

Martínez-Alfaro M., Hernández-Cortés D., Wrobel K., Cruz-Jiménez G., Rivera-Leyva J.C., Piña-Zentella R.M. and Cárabez Trejo A. (2012). Effect of melatonin administration on DNA damage and repair responses in lymphocytes of rats subchronically exposed to lead. Mutat. Res. 742 (1-2), 37-42.

DOI: $10.1016 /$ j.mrgentox.2011.11.011

Martínez-Arredondo J.C., Ortega-Chávez V.M. and Ramos Arroyo Y.R. (2013). Índices climatológicos regionales para la Sierra Gorda de Guanajuato. Acta Universitaria 23 (6), 10-25.

Méndez-Gómez J., García-Vargas G.G., López-Carrillo L., Calderón-Aranda E.S., Gómez A., Vera E., Valverde M., Cebrián M.E. and Rojas E. (2008). Genotoxic effects of environmental exposure to arsenic and lead on children in Region Lagunera, Mexico. Ann. N. Y. Acad. Sci. 1140, 358-367. DOI: 10.1196/annals.1454.027

Miranda-Gasca M.A. (1978). Regional geological and geochemical study area Xichú, Guanajuato. Bol. Soc. Geol. Mexicana. 39 (2), 101-106.

Moreno M.E., Acosta-Saavedra L.C., Meza-Figueroa D., Vera E., Cebrián M.E., Ostrosky-Wegman P. and Calderón-Aranda E.S. (2010). Biomonitoring of metal in children living in a mine tailings zone in Southern 
Mexico: A pilot study. Int. J. Hyg. Environ. Health 213 (4), 252-258.

DOI: 10.1016/j.ijheh.2010.03.005

Peraza M.A., Ayala-Fierro F., Barber DS., Casarez E. and Rael L.T. (1998). Effects of micronutrients on metal toxicity. Environ. Health Perspect. 1, 203-216.

DOI: 10.1289/ehp.98106s1203

Ramos-Arroyo Y.R., Prol-Ledesma R.M. and SiebeGrabach C. (2004). Geological and mineralogical characteristics and history of an extraction district of Guanajuato, Mexico. Geochemical possible scenarios for mining waste. Rev. Mex. Cienc. Geol. 2, 268-284.

Ramos-Arroyo Y.R. and Siebe-Grabach C. (2006). Strategy for the identification of tailings with environmental risk potential in a mining district: Case study in the Guanajuato district, Mexico. Rev. Mex. Cienc. Geol. 23 (1), 54-74.

Salas-Megchún E.F. (2014). Geoquímica y mineralogía de jales en mina Aurora, Xichú, Guanajuato. Tesis de Maestría. Centro de Geociencias, Universidad Nacional Autónoma de México. Ciudad de México, México, 107 pp.

Saleha-Banu B., Danadevi K., Jamil K., Ahuja Y.R., Visweswara-Rao K. and Ishaq M. (2001). In vivo genotoxic effect of arsenic trioxide in mice using comet assay. Toxicology 162 (3), 171-177.

DOI: $10.1016 / \mathrm{S} 0300-483 \mathrm{X}(01) 00359-6$

SEMARNAT (2005). Norma Oficial Mexicana NOM141-SEMARNAT-2003. Que establece el procedimiento para caracterizar los jales, así como las especificaciones y criterios para la caracterización y preparación del sitio, proyecto, construcción, operación y postoperación de presas de jales. Secretaría de Medio Ambiente y Recursos Naturales. Diario Oficial de la Federación. February 16.

SEMARNAT (2007). Norma Oficial Mexicana NOM147-SEMARNAT/SSA1-2004. Que establece los criterios para determinar las concentraciones de remediación de suelos contaminados por arsénico, bario, berilio, cadmio, cromo hexavalente, mercurio, níquel, plata, plomo, selenio, talio y/o vanadio. Secretaría de Medio Ambiente y Recursos Naturales. Diario Oficial de la Federación. March 2.

Singh N.P., McCoy M.T., Tice R.R. and Schneider E.L. (1988). A simple technique for quantitation of low levels of DNA damage in individual cells. Exp. Cell. Res. 175 (1), 184-191.

DOI: $10.1016 / 0014-4827(88) 90265-0$

SSA (2002). Norma Oficial Mexicana NOM-199SSA1-2000. Salud ambiental. Niveles de plomo en sangre y acciones como criterios para proteger la salud de la población expuesta no ocupacionalmente. Secretaría de Salud. Diario Oficial de la Federación, October 18.

SSA (2017). Modificación de los numerales 3, 6.1, tabla 1, así como los numerales 1 y 1.1.10, del Apéndice A, de la Norma Oficial Mexicana NOM-199-SSA1-2000. Salud ambiental. Niveles de plomo en sangre y acciones como criterios para proteger la salud de la población expuesta no ocupacionalmente, publicada el 18 de octubre de 2002. Secretaría de Salud. Diario Oficial de la Federación. August 30.

Trejo-Acevedo A., Díaz-Barriga F., Carrizales L., Domínguez G., Costilla R., Ize-Lema I., Yarto-Ramírez M., Gavilán-García A., Mejía-Saavedra J. and Pérez-Maldonado I.N. (2009). Exposure assessment of persistent organic pollutants and metals in Mexican children. Chemosphere 74 (7), 974-980.

DOI: $10.1016 /$ j.chemosphere.2008.10.030

WHO (2017). Global database on child growth and malnutrition. World Health Organization [online]. http:// www.who.int/nutgrowthdb/about/introduction/en/ index5.html 12/11/2018.

Yáñez L., García-Nieto E., Rojas E., Carrizales L., Mejía J., Calderón J., Razo I. and Díaz-Barriga F. (2003). DNA damage in blood cells from children exposed to arsenic and lead in a mining area. Environ. Res. 93 (3), 231-240. DOI: 10.1016/j.envres.2003.07.005 